This item was submitted to Loughborough's Research Repository by the author.

Items in Figshare are protected by copyright, with all rights reserved, unless otherwise indicated.

\title{
Developing a collaborative design toolkit for the personalisation of running
} shoes

PLEASE CITE THE PUBLISHED VERSION

http://ijg.cgpublisher.com/product/pub.154/prod.725

PUBLISHER

(C) (individual papers), the author(s); (c (selection and editorial matter) Common Ground

VERSION

VoR (Version of Record)

LICENCE

CC BY-NC-ND 4.0

REPOSITORY RECORD

Head, Matthew J., and C. Samantha Porter. 2019. "Developing a Collaborative Design Toolkit for the Personalisation of Running Shoes”. figshare. https://hdl.handle.net/2134/11862. 


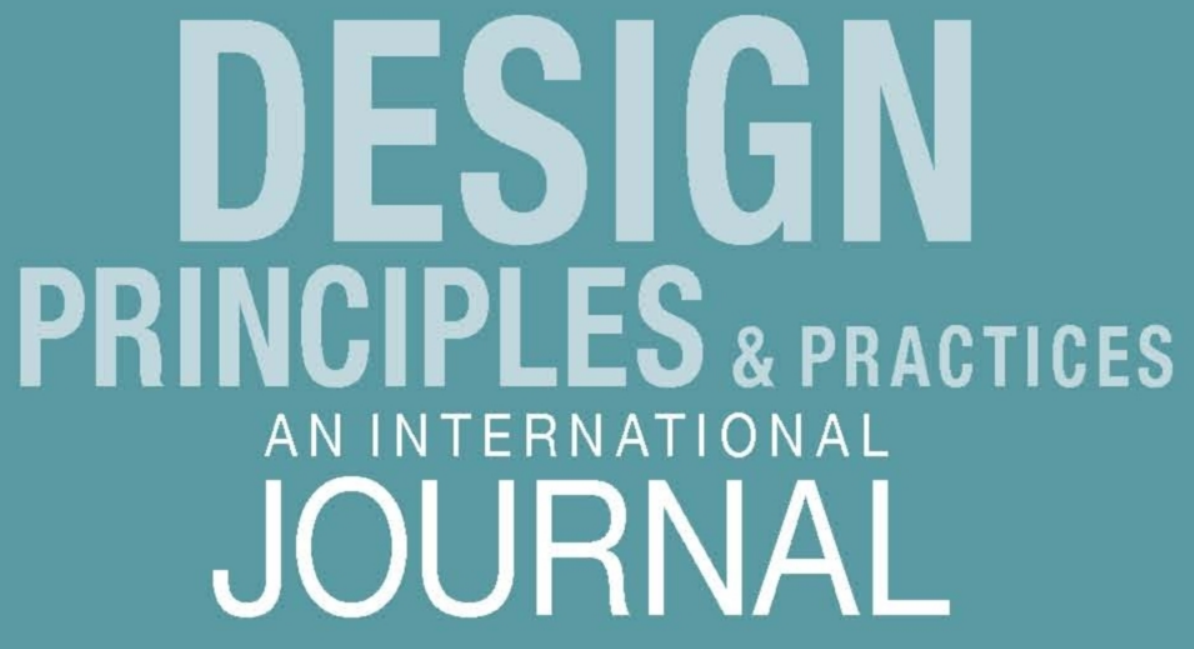

Volume 5, Issue 6

Developing a Collaborative Design Toolkit for the Personalisation of Running Shoes

Matthew Head and C. Samantha Porter 
DESIGN PRINCIPLES AND PRACTICES: AN INTERNATIONAL JOURNAL http://www.Design-Journal.com

First published in 2011 in Champaign, Illinois, USA

by Common Ground Publishing LLC

www.CommonGroundPublishing.com

ISSN: 1833-1874

(C) 2011 (individual papers), the author(s)

(c) 2011 (selection and editorial matter) Common Ground

All rights reserved. Apart from fair dealing for the purposes of study, research, criticism or review as permitted under the applicable copyright legislation, no part of this work may be reproduced by any process without written permission from the publisher. For permissions and other inquiries, please contact

<cg-support@commongroundpublishing.com>.

DESIGN PRINCIPLES AND PRACTICES: AN INTERNATIONAL JOURNAL is peerreviewed, supported by rigorous processes of criterion-referenced article ranking and qualitative commentary, ensuring that only intellectual work of the greatest substance and highest significance is published.

Typeset in Common Ground Markup Language using CGPublisher multichannel typesetting system

http://www.commongroundpublishing.com/software/ 


\title{
Developing a Collaborative Design Toolkit for the Personalisation of Running Shoes
}

\author{
Matthew Head, Loughborough University, Leicestershire, UK \\ C. Samantha Porter, Loughborough University, Leicestershire, UK
}

\begin{abstract}
Sport footwear is an area where collaborative design is already happening with consumers able to personalise the aesthetics of their footwear using the internet. Aesthetics do not appear to be the consumers' primary interest when purchasing running shoes; a need was identified for better fitting and performing running shoes than is currently available; a large number of consumers are also reluctant to purchase online, preferring to purchase from specialist running stores. In this paper the development of an in store personalisation service with a primary focus of delivering better fitting and performing footwear is detailed. Experts in biomechanics and additive manufacturing were consulted, and focus groups, interviews and surveys were conducted to ensure implementation of an effective service that empowered the consumer, putting them at the centre of a collaborative design process. $A$ design toolkit was developed for the service (www.yourstep.co.uk) and tested online. The results are discussed and future developments defined. This research forms part of the Elite to High Street project, a five-year multi-million pound IMCRC-funded interdisciplinary project run by Loughborough University with industrial partners including; New Balance, UK Sport and 3D Systems.
\end{abstract}

Keywords: Sports Footwear, Running Shoes, Personalisation, Collaborative, Customer, Toolkit

\section{Introduction}

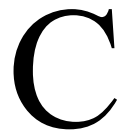

ATERING TO 'MARKETS of one' has proven difficult for many companies to implement: Levi's, Dell and Mattel all ultimately failed in their attempts to offer personalised goods (Williams, 2010; Franke \& Piller, 2004). In the sports footwear market there appears to be no such issue, several companies offer personalised footwear, enabled through online collaborative design toolkits: Nike iD (see figure 1), Mi Adidas and Your Reebok are some of the most prominent. These services allow the consumer to personalise the aesthetics, primarily the colours, for a range of different footwear.

For running shoes, the largest selling shoe within the sports footwear market (NPD Group Inc., 2008), research has identified that many runners require better fitting and performing footwear than is currently available (Babb, 2008; Stuhlfaut \& Sullivan, 2007; Mintel Marketing Intelligence, 2007; Witana, 2004; Goonetillek, 2003) and place greater importance on the comfort and fit of their footwear than the aesthetics (Head, Porter \& Summerskill, 2009; Marti, 1989; Collazzo, 1988). As a consequence, many consumers prefer purchasing in stores (Head, Porter \& Toon, 2010; Mintel Marketing Intelligence, 2008), where they are able to try the footwear on (Redaelli, 2005).

The current design toolkits are based online, reducing the potential for consumers to foster product attachment, and do not allow collaborative design of the footwear's comfort and performance beyond that which can be found across a standard shoe range. To successfully

Design Principles and Practices: An International Journal C $O M M O N$ Volume 5, Issue 6, 2011, http://www.Design-Journal.com, ISSN 1833-1874 $G \quad R \quad O \quad U \quad N \quad D$ (C) Common Ground, Matthew Head, C. Samantha Porter, All Rights Reserved, Permissions: cg-support@commongroundpublishing.com 
implement a service delivering personalised goods it is important to cater to consumer needs (Franke, Schreier \& Kaiser, 2010), in this case there appears to be a disconnection between what many runners desire and the currently available options.

The aim of this research was to develop a collaborative design toolkit for the personalisation of running shoes. The primary focus of this paper is the toolkit development and testing. To enable development, research was required to establish a service framework for personalised sports footwear.

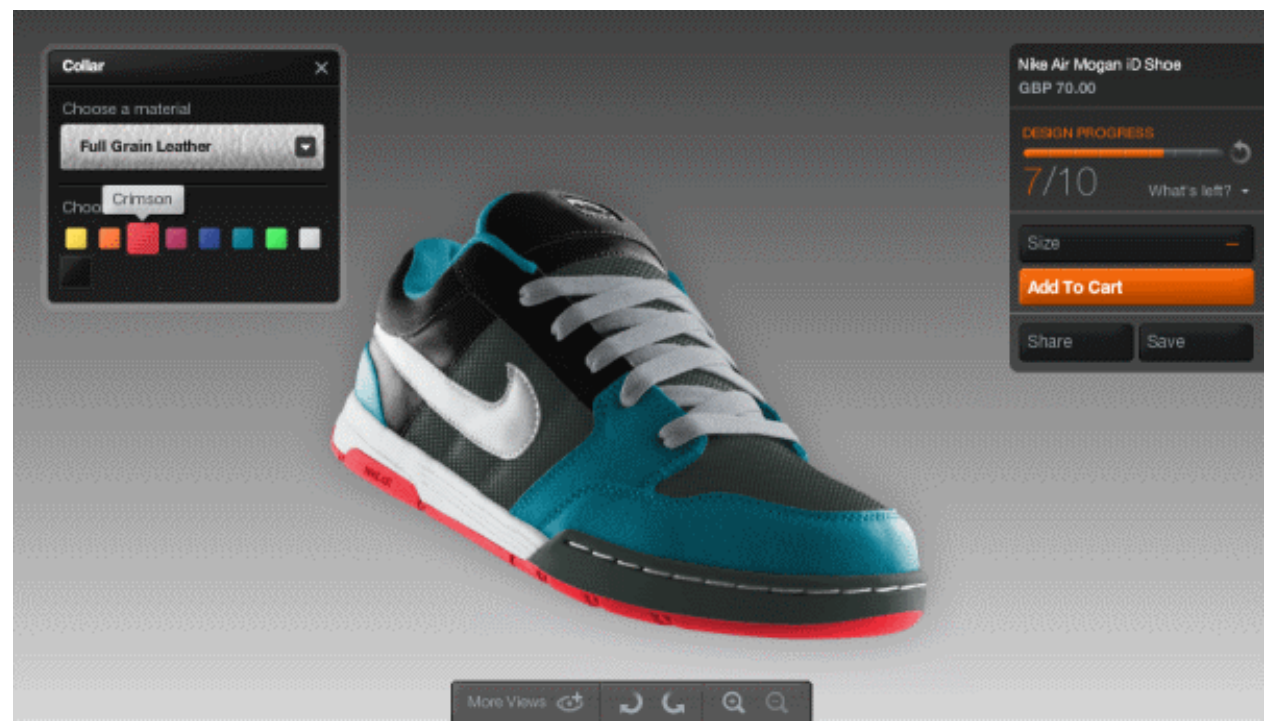

Figure 1: The Nike ID System

\section{Research Activities}

To develop a toolkit it was important to understand consumers' running shoe purchase preferences and attitudes towards running shoe personalisation. The author found limited literature for these subjects and it was, therefore, desirable to collect both qualitative and quantitative data. Quantitative data were used to support/contest the findings in the current literature and qualitative data were used to provide the specific details necessary to aid the development of a toolkit for running shoe personalisation. These data were collected using three different methods, identified as appropriate; focus groups, questionnaires and interviews.

\section{Focus Group}

Twenty running shoe owners were chosen as participants; they were split into four separate sessions: male and female runners and male and female non-runners. Non-runners used their running shoes predominantly for activities other than running. The groupings were used to encourage a comfortable and suitable environment in which everyone could contribute (Langford \& McDonagh, 2003). 


\section{Questionnaires}

Two instances of questionnaires were employed: one at the London Marathon Exposition and another online. Forty-two participants (31 males and 11 females) were solicited at the Exposition: two were non runners, the rest ran at least 5 miles a week, over $70 \%$ ran between 11 and 40 miles a week. This questionnaire was designed to focus primarily on consumers' running shoe purchase preferences.

Participants completing the online questionnaire were asked to design running shoes using an existing personalisation service and then answer questions concerning their experience. They were recruited primarily from the Loughborough University student population. Fortyone participants completed the survey in total; there were no exclusion criteria with respect to their running habits.

\section{Interviews}

Semi-structured interviews were carried out in a specialist running store, identified in the literature as the most popular purchase location for runners (Mintel Marketing Intelligence, 2008; Stuhlfaut \& Sullivan, 2007). There were two main intentions of the interviews: to obtain an overview of the service provided and to understand consumers' purchase decisions in these stores. Interviews were carried out with five assistants and four customers at four different stores within the United Kingdom.

The data captured by these methods were used to help define the product and service specifications (see table 1). 
Table 1: Key Requirements from the Product and Service Specifications

\begin{tabular}{|c|c|c|}
\hline \multicolumn{2}{|c|}{ SPECIFICATION } & \multirow{2}{*}{\begin{tabular}{|l|} 
INFORMATION \\
They should be designed to look practical but \\
also be attractive.
\end{tabular}} \\
\hline PRODUCT & $\begin{array}{l}\text { The shoes should be designed, } \\
\text { primarily, to look functional. }\end{array}$ & \\
\hline & \begin{tabular}{|l|} 
The shoe design should focus \\
on providing good comfort and \\
support to the consumer.
\end{tabular} & $\begin{array}{l}\text { The shoe should provide improved comfort and } \\
\text { support in comparison with a standard shoe } \\
\text { and current personalisation services. }\end{array}$ \\
\hline & $\begin{array}{l}\text { A carefully considered range of } \\
\text { aesthetic choices should be } \\
\text { offered. }\end{array}$ & $\begin{array}{l}\text { Colours provided should be carefully con- } \\
\text { sidered to minimise consumer regret and poten- } \\
\text { tial brand damage. } \\
\text { Key conservative running shoe colours s hould } \\
\text { be provided for selection: blue, white, red and } \\
\text { black. }\end{array}$ \\
\hline & $\begin{array}{l}\text { Consumers should be able to } \\
\text { produce a unique pair of shoes. }\end{array}$ & $\begin{array}{l}\text { This may be through the comfort and support } \\
\text { and/ or the aesthetic choices offered. }\end{array}$ \\
\hline & $\begin{array}{l}\text { The shoes must be priced com- } \\
\text { petitively and appropriately. }\end{array}$ & $\begin{array}{l}\text { The target price premium of the shoes should } \\
\text { be around } 10 \% \text { in comparison with equivalent } \\
\text { standard shoes. }\end{array}$ \\
\hline \multirow[t]{5}{*}{ SERVICE } & $\begin{array}{l}\text { Primarily, the service should be } \\
\text { carried out in an in store envir- } \\
\text { onment. }\end{array}$ & $\begin{array}{l}\text { Shop assistants should be utilised effectively, } \\
\text { primarily for measurements and fitting. }\end{array}$ \\
\hline & $\begin{array}{l}\text { Consumers should be allowed } \\
\text { a suitable time frame with } \\
\text { which to complete the service. }\end{array}$ & $\begin{array}{l}\text { The fitting element of the service should be able } \\
\text { to be completed within } 20 \text { minutes but con- } \\
\text { sumers should be able to spend over } 20 \text { minutes } \\
\text { configuring their shoe aesthetically }\end{array}$ \\
\hline & $\begin{array}{l}\text { The service should employ a } \\
\text { strong, consistent theme. }\end{array}$ & All elements of the service should be cohesive. \\
\hline & $\begin{array}{l}\text { Consumers should feel comfort- } \\
\text { able during the whole experi- } \\
\text { ence. }\end{array}$ & $\begin{array}{l}\text { Shop assistants should ensure consumers are } \\
\text { comfortable during the fitting process. } \\
\text { The consumers should be allowed privacy, if } \\
\text { desired, to make their aesthetic selections. This } \\
\text { may be undertaken in a separate location. }\end{array}$ \\
\hline & $\begin{array}{l}\text { Consumers should be made to } \\
\text { feel part of the experience. }\end{array}$ & $\begin{array}{l}\text { The consumer's opinion should appear import- } \\
\text { ant during the whole process. They should be } \\
\text { involved in every decision. } \\
\text { Contact should be maintained with the con- } \\
\text { sumer during the waiting period. }\end{array}$ \\
\hline
\end{tabular}




\section{Service Development}

The development of the service framework and the resultant product concept provided a structure into which the toolkit could then be integrated.

\section{Service Framework}

Guidelines on service and experience design were consulted during the framework definition (Bardill, Herd, \& Karamanoglu, 2007; Pine \& Gilmore, 1998; Scheuing \& Johnson, 1989); implementing an effective service will increase the potential of retaining customers (Polyani, 1958).

Customers will face a similar process regardless of which service they use to purchase their running shoes, simplified into four steps below (see table 2).

Table 2: The Four Steps to Delivering Running Shoes

\begin{tabular}{|l|l|l|}
\hline NO. & STEPS & DETAIL \\
\hline 1. & Data Collection & Understanding what the customer wants \\
\hline 2. & Preference Selection & Providing the customer with the options for selection \\
\hline 3. & Shoe Fitting & Establishing the customer has the correct footwear sizing \\
\hline 4. & Shoe Delivery & Customer receives the chosen footwear \\
\hline
\end{tabular}

These steps can be adapted for a potential personalisation service using Shostack's molecular modelling approach (1982), and expanded to include required secondary services (see figure 2). These different parts of the service are detailed below.

\section{Data Collection}

Comfort and support were identified as the most important aspects to many wearers of running shoes therefore it was important to offer footwear personalised by their fit, this requires a set of measurements of the foot. Suitable methods are being investigated as part of this project (Salles \& Gyi, 2010) and externally (Krauss, et al., 2010). Capturing of personal data regarding the customers' running shoe use is necessary to define the required performance aspects for the footwear product.

\section{Preference Selection}

In addition to the personalisation of the fit, the customer will be provided with comfort and performance options to improve their experience i.e. choice of different uppers.

Aesthetics, while not as important as the comfort or performance of the footwear, are still important to those who purchase running shoes (Stuhlfaut \& Sullivan, 2007). Runners desire that aesthetic options provided should be simple and include 'traditional' colour schemes (Head, et al., 2010). 


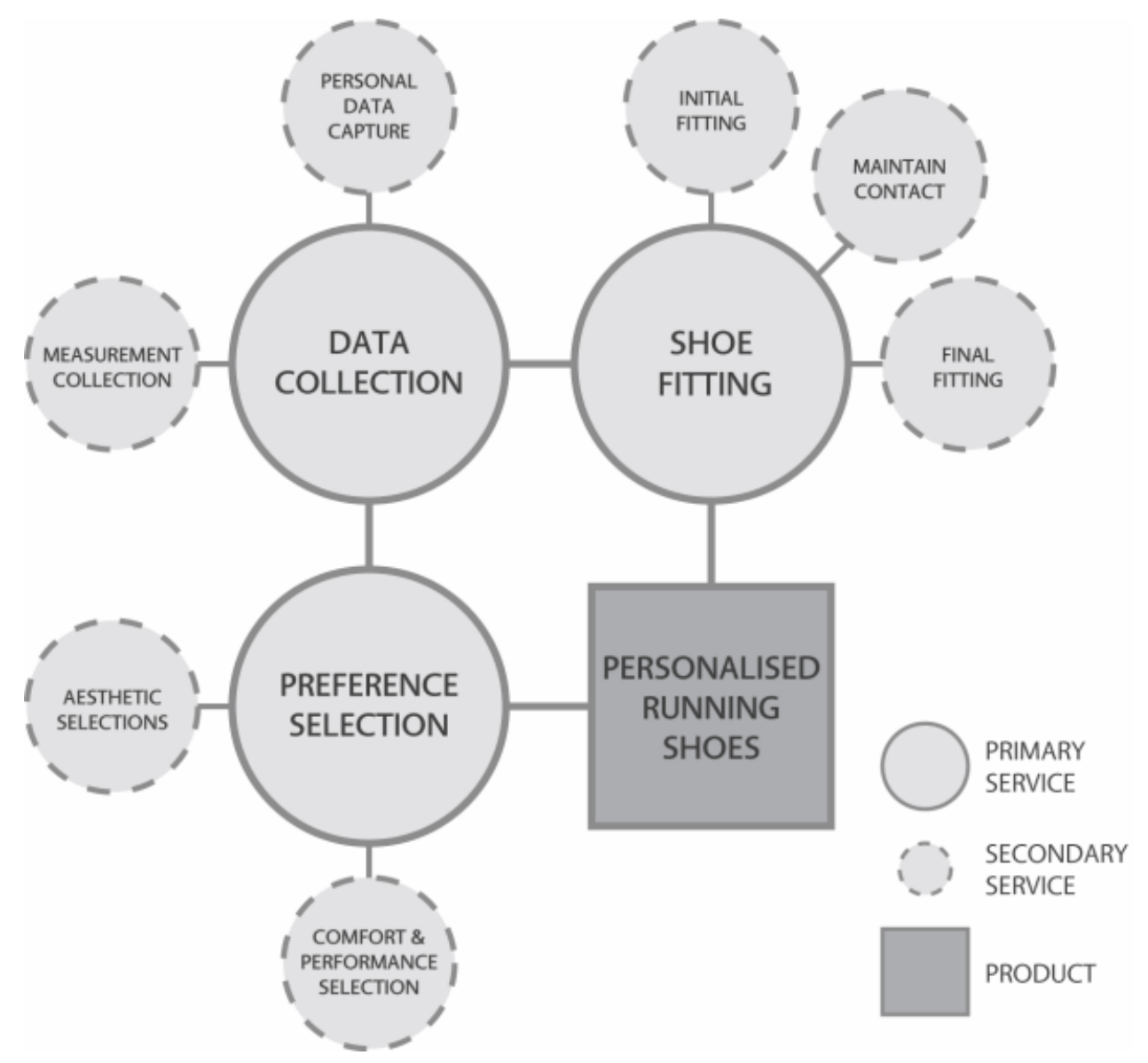

Figure 2: Service Model for Delivering Personalised Running Shoes

\section{Shoe Fitting}

Customers stressed the importance of trying their footwear before purchase (Head, et al., 2010; Mintel Marketing Intelligence, 2010). Fitting would be split into two stages: an initial fitting of a configurable shoe that could be prepared in store and, once the customer had committed, a final fitting of the personalised footwear. Maintaining a relationship with the customer during this period was considered essential, ensuring they felt valued and minimising any regrets they may have about their purchase (Yessin, 2008; Herd, Bardill \& Karamanoglu, 2007).

After considering the different services required, accountability for their delivery was considered (see table 3 ). The practicality of capturing the measurements and fitting of the shoes requires a store assistant. The primary responsibility for all the other tasks was assigned to the toolkit, enabling easy data capture for the provider and privacy, where required, for the consumer. A store assistant would be available to alleviate any uncertainty that the customer experienced at any stage. Figure 3 illustrates a potential in store process. 
Table 3: Service Responsibilities for Delivering Personalised Running Shoes

\begin{tabular}{|l|l|l|}
\hline PRIMARY SERVICE & \multicolumn{1}{|c|}{ SECONDARY SERVICE } & \multicolumn{1}{c|}{$\begin{array}{c}\text { PRIMARY } \\
\text { RESPONSIBILITY }\end{array}$} \\
\hline \multirow{2}{*}{ DATA COLLECTION } & Personal data capture & Toolkit \\
\cline { 2 - 3 } & Measurement collection & Store Assistant \\
\hline \multirow{2}{*}{$\begin{array}{l}\text { PRELERERENCE } \\
\text { SHOE FITTING }\end{array}$} & Comfort \& Performance selections & Toolkit \\
\cline { 2 - 3 } & Aesthetic selections & Toolkit \\
\hline & Initial fitting & Store Assistant \\
\cline { 2 - 3 } & Maintain Contact & Store Assistant \\
\cline { 2 - 3 } & Final fitting & Store Assistant \\
\hline
\end{tabular}

\section{Product Concept}

A basic personalised running shoe concept (see figure 4) was developed with consultation from researchers in additive manufacturing to ensure that production was feasible and costeffective (Toon, et al., 2008; Hague, Campbell \& Dickens, 2003). The biomechanics and anthropometry to define the measurements required to specify such a product were also identified on the basis of the work of other researchers on the project (Salles \& Gyi, 2010). Outlined in the diagram are the different aspects of the shoe concept and the information required from the consumer to be able to specify this concept, classified into three different categories; questions $(\mathrm{Q})$, measurements $(\mathrm{M})$ and choices $(\mathrm{C})$. The shoe offers a mix of modular choices: the midsole, uppers and colours and personalisation: the insole and midsole. This is a cost-effective concept that offers the potential for improved fit, support and performance as compared to current standard running shoes. 


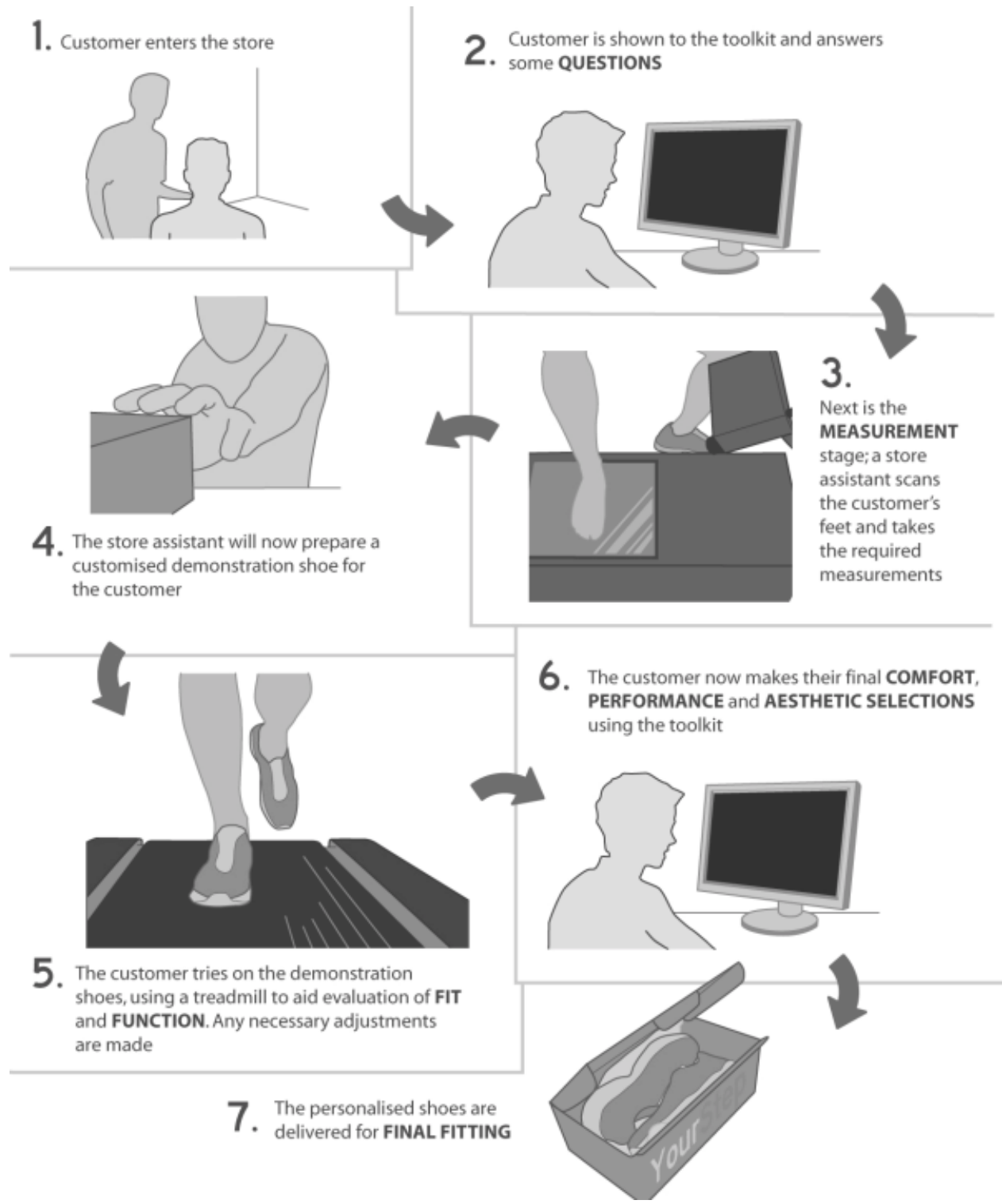

Figure 3: Potential in Store Process for Delivering Personalised Running Shoes 


\section{COMPONENT DETAILS}

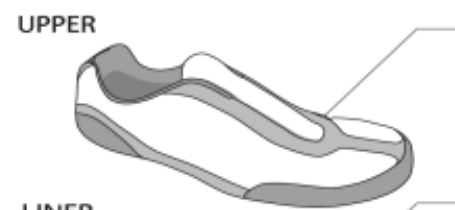

3 UPPER TYPES

3 UPPER HEIGHTS

ALL CONDITIONS/PERFORMANCE/ROAD | LOW/MEDIUM/HIGH

Established using:

Q Running surfoce

Established using:

Q Distance covered

M Dorsum/Hallux/MPs height

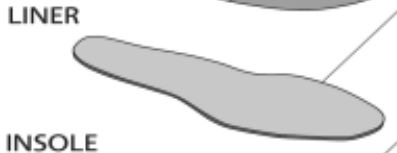

3 DIFFERENT FABRIC LINERS

Provide a different tactile finish

Established using:

Established using:
C Personal preference

LEGEND

PERSONALISED INSOLE featuring:

- Plantar profile that matches individual's feet

Q Question

M Measurement

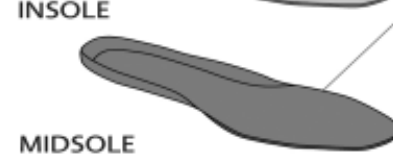

Established using: c Personal preference
M Footscan

MIDSOLE

CONFIGURABLE MIDSOLE featuring:

1 - Extra Medial/Lateral support depending on level of Pronation/Supination - Different level of cushioning if user is a rear foot striker

2 - 3 different support levels for the arch area: STIFF/NEUTRAL/SOFT Different level of cushioning if user is a mid foot striker

OUTSOLE

3 - Different level of cushioning if user is a fore foot striker

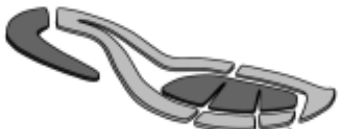

Established using:

M 20 analysis on treodmill (Pronation/Supination)

M Body weight (Level of cushioning)

M Plantar pressure analysis using treodmill (Foot strike point)

Q Running shoe use (Foot strike point, Level of cushioning)

3 OUTSOLE TYPES

TRAIL/ROAD/LIGHTWEIGHT

Established usine:

Q Running surface

Q Distance covered

M Body weight Q Frequency of use

\section{OTHER OPTIONS}

SHOE SIZING

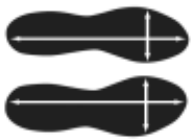

- Independent shoe sizes for each foot

- Shoe sizes available from 3 - 15

-3 different shoe widths:

NARROW/MEDIUM/WIDE

Established Using:

M Foot width \& length

Q Gender

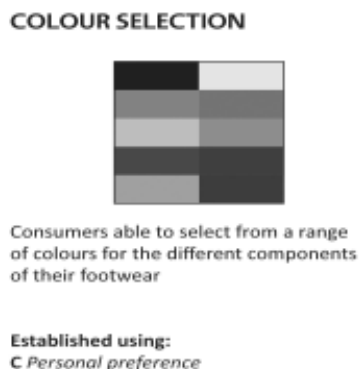

CPersonat using:
MIDSOLE PERSONALISATION

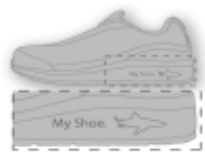

Personal designs etched to the midsole of the shoes through additive manufacturing

Established using: c Personal preference

Figure 4: Personalised Running Shoe Concept

\section{Developing the Toolkit}

With a service framework and product concept defined the toolkit could be developed. Outlined in this section is a summary of the process. 


\section{Defining Content and Structure}

The information required from the customer to specify the product was organised into the relevant sections of the framework (see table 4) and an interactive flow diagram was developed detailing the data collection process. After informal analysis by the research team, two important additions were made at this stage:

- Measurement information provided after personal data capture: the customer may wish to understand the measurement process before they progress.

- Information to occupy customer when idle: during the initial fitting the customer may be unoccupied as the store assistant prepares the shoe. The toolkit should provide information regarding the service/running shoes, potentially increasing their knowledge in the field and leading to better decisions.

The final structure of the toolkit is shown in figure 5 .

Table 4: Required Customer Data for Personalised Running Shoe Concept Categorised by Service

\begin{tabular}{|l|l|l|l|l|}
\hline \multirow{2}{*}{ SERVICE } & \multicolumn{2}{|c|}{ DATA COLLECTION } & \multicolumn{1}{|c|}{ PREFERENCE SELECTIONS } \\
\cline { 2 - 5 } & $\begin{array}{l}\text { Personal Data } \\
\text { Capture }\end{array}$ & $\begin{array}{l}\text { Measurement } \\
\text { Collection }\end{array}$ & $\begin{array}{l}\text { Comfort \& } \\
\text { Performance } \\
\text { Selections }\end{array}$ & $\begin{array}{c}\text { Aesthetic } \\
\text { Selections }\end{array}$ \\
\hline RESPONSIBILTY & \multicolumn{1}{|c|}{ Toolkit } & Store Assistant & \multicolumn{1}{|c|}{ Toolkit } & \multicolumn{1}{|c|}{ Toolkit } \\
\hline INFORMATION & $\begin{array}{l}\text { Q Running } \\
\text { surface } \\
\text { Q Distance } \\
\text { covered } \\
\text { Q Gender } \\
\text { Q Running shoe } \\
\text { use } \\
\text { Q Running } \\
\text { surface } \\
\text { Q Frequency of } \\
\text { use }\end{array}$ & $\begin{array}{l}\text { M Dorsum height } \\
\text { M Hallux height } \\
\text { M MPJ height } \\
\text { M Foot scan } \\
\text { M 2D analysis } \\
\text { M Body weight } \\
\text { M Plantar } \\
\text { pressure } \\
\text { M Foot width \& } \\
\text { length }\end{array}$ & $\begin{array}{l}\text { C Outsole type } \\
\text { Celection } \\
\text { C Midsole } \\
\text { personalisation }\end{array}$ \\
\hline
\end{tabular}

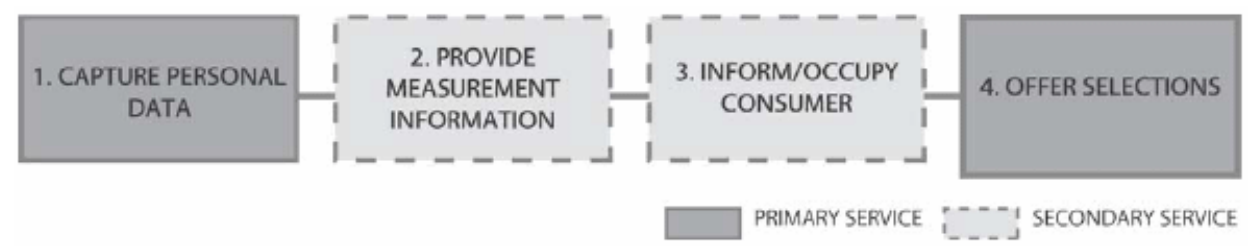

Figure 5: Running Shoe Personalisation Toolkit Structure 


\section{Navigation Style}

It was important that all the required data was captured by the toolkit, because of this a procedural rule navigation system was chosen for the overall toolkit; the user could not move forward without making a selection. Once they had made that decision they were able to go back and change their input at a later point, before they submitted, if they wished.

Within the aesthetic selections decision-rule-based navigation systems were more desirable as they encouraged creativity, allowing users to select options they wanted, in whichever order. The shoe could still be produced without all the selections being made; a warning message would ensure they were finished.

\section{Development Process and Software}

Development was iterative with the prototypes tested informally, often by people unfamiliar with the project, ensuring development retained the appropriate focus.

The toolkit needed to be easy to understand and use. Guidelines in interaction, human centered, experience and usability design were consulted during the toolkit development (Moggridge, 2007; Krug, 2006; Lazar, 2006; Benyon, Turner \& Turner, 2005; Rogol \& Piller, 2004; International Standards Office, 2002; Nielsen \& Tahir, 2002; Raskin, 2000) to ensure a toolkit that was consistent, well structured and enjoyable to use.

The content and graphics for the toolkit were created using Adobe Illustrator and then imported into Adobe Flash where interactivity was added using Flash's native scripting language, Actionscript 2.0. The toolkit was developed so that all information inputted by the user was saved to an XML file. To enable this, an Apache Server was installed alongside PHP.

\section{Theme and Brand}

A strong, consistent theme was important to the success of the toolkit and the service. A colour scheme was selected with the aid of Adobe Kuler and research on colour utilisation within a purchasing environment (Middlestadt, 1990; Bellizzi, Crowley \& Hasty, 1983). The intention was to select colours neither strongly masculine nor feminine. 'YourStep' was selected as the service name after an informal brainstorm within the Design Ergonomics research group at Loughborough University because it was felt that it strongly represented the individuality of the consumers with regards to their locomotion.

\section{The YourStep Toolkit}

The final result of the development process was the YourStep toolkit, designed to deliver an enjoyable, satisfying experience for consumers wishing to personalise their own running shoes. Figure 6 provides an annotated screen shot of the layout for the main screen of the toolkit, table 5 details the different components identified in this screen shot. 


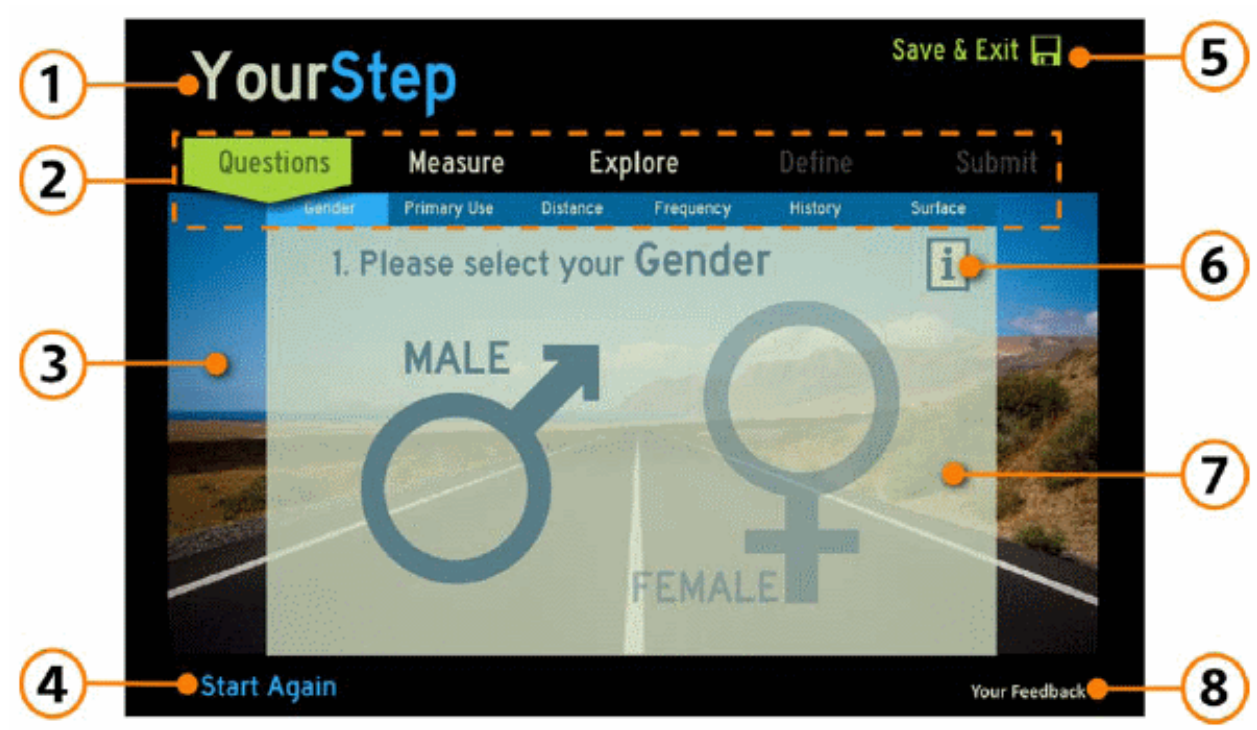

Figure 6: Layout of Main Screen for Toolkit

Table 5: Legend for Toolkit Layout

\begin{tabular}{|c|c|c|}
\hline NO. & DESCRIPTION & INFORMATION \\
\hline 1. & YourStep logo & $\begin{array}{l}\text { Defines identity of service, clicking will return user to } \\
\text { 'homepage'. }\end{array}$ \\
\hline 2. & Navigation menu & $\begin{array}{l}\text { Indicates current section of service, and position within that } \\
\text { section. Can be used to navigate between and within sections. }\end{array}$ \\
\hline 3. & Background image & $\begin{array}{l}\text { This changes according to the user's selections e.g. if they } \\
\text { select that they run on road, an open road image appears. }\end{array}$ \\
\hline 4. & 'Start Again' button & Takes the user to back to the start, data is lost. \\
\hline 5. & 'Save \& Exit' feature & $\begin{array}{l}\text { Allows the user to save their progress for resumption at a } \\
\text { more suitable time and, potentially, location. }\end{array}$ \\
\hline 6. & Information button & $\begin{array}{l}\text { Provides information regarding the content displayed on the } \\
\text { data collection space }\end{array}$ \\
\hline 7. & Data collection space & $\begin{array}{l}\text { The main interaction point for the consumer; all questions, } \\
\text { choices and information are displayed here }\end{array}$ \\
\hline 8. & Feedback button & $\begin{array}{l}\text { Users can submit comments, problems and ideas regarding } \\
\text { the service }\end{array}$ \\
\hline
\end{tabular}

These components remain throughout the majority of the customer's use of the toolkit. Some are essential: the navigation menu allows the user to easily identify their current stage in the process and navigate to required content. The information button provides the initial point of reference if the user is experiencing any doubts. Others aim to enhance the user's experi- 
ence, e.g. the intention of changing the background image is to make the user feel that the service is being personalised to them. The feedback button enables the user to directly contribute towards the improvement of the service.

\section{Main Sections}

\section{Questions}

A screenshot from the 'Question' section is shown in figure 6. The customer is provided with six questions, targeted to collect the required personal data on the user's running shoe preferences.

\section{Measure}

In this section the user can retrieve information on the measurements that will be taken before they choose to proceed (see figure 7).

\section{Explore}

The user is presented with the model of a shoe that can be manipulated to reveal different information about their individual personalised footwear (see figure 8). This section was developed to occupy the customer as they wait for footwear to be prepared for fitting.

\section{Define}

The 'Define' section is where the user is presented with the range of options for selection. They are split into three sections: the comfort and performance options (see figure 9), the colour selection section (see figure 10), and the midsole personalisation screen (see figure 11). Within the colour selection section tools have been added to aid the user: the gallery (see figure 12) and the random colour and colour guidance features.

The gallery provides a range of shoes coloured by peers that the user can select or modify for themselves. Clicking the 'Random Colours' button on the main design screen automatically colours the shoe model; people who are short of time or who do not place a priority on the aesthetics of their footwear may find this a useful feature. The colour guidance function restricts the colour selections for the shoe, allowing only complementary colours to be selected, with the intention of minimising the regret a consumer may experience post purchase. 

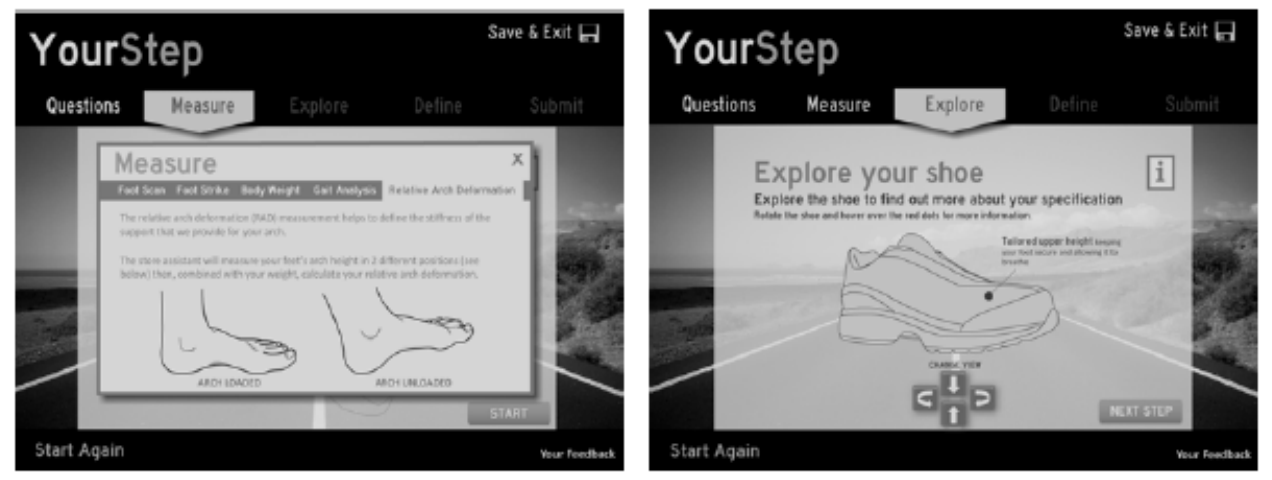

Figures $7 \&$ 8: Measurement Information (1) \& the 'Explore' Section (r)
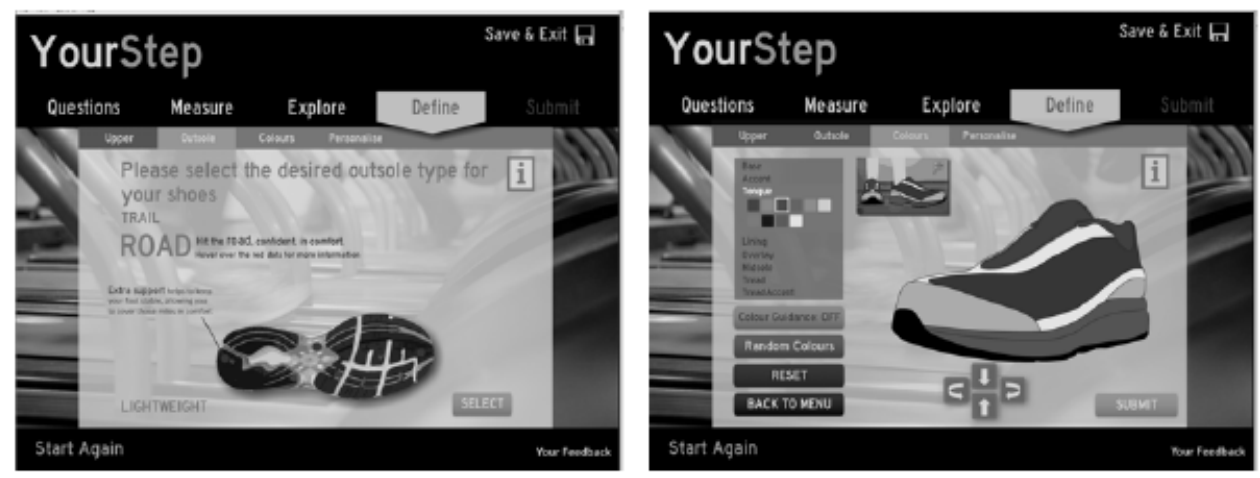

Figures $9 \&$ 10: Outsole Choice in the 'Define' Section (l) \& the Colour Selection Screen (r)
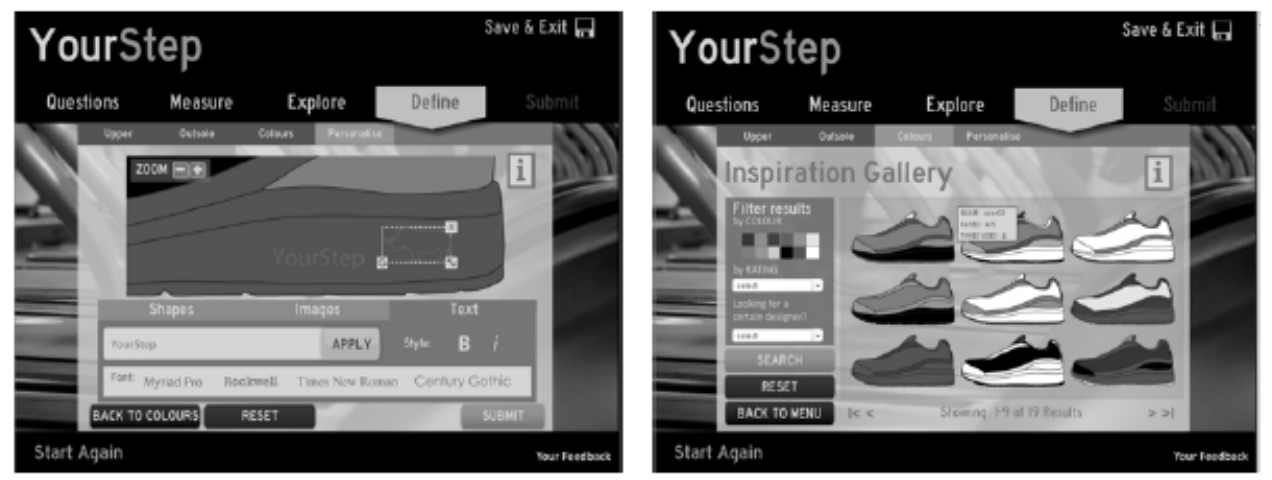

Figures 11 \& 12: The Midsole Personalisation Screen and (1) The 'Inspiration Gallery' (r) 


\section{Testing}

The main aim during the testing phase was to test and evaluate a prototype of the toolkit, in order to outline and define further development.

\section{Objectives}

To achieve this aim a set of objectives were identified:

- To assess the usability of the toolkit

- To assess the visual components of the toolkit e.g. layout, colours, image quality

- To assess the functionality of the toolkit e.g. does the toolkit perform its tasks effectively?

- To assess the overall experience of using the toolkit

Testing of the toolkit was split into four different categories:

- Heuristic Evaluation: inspection of the toolkit's usability by postgraduate students studying interaction design.

- Expert testing: professionals in the field of sportswear, interaction and industrial design assess the toolkit design, providing response via tailored questionnaires.

- Laboratory testing: runners and non-runners completing tasks under supervision, simulating a purchase environment, with semi-structured interviews conducted after.

- Online testing: large sample data collection exercise using a web hosted version of the toolkit and questionnaire.

These were carried out sequentially, the first three types of evaluation were formative, allowing for updates to the toolkit between each test. The final test session, the online testing, was summative and the key results are described below.

\section{Methodology for Online Testing}

The toolkit was hosted on the internet (www.yourstep.co.uk) so that it could be accessed from anywhere. The toolkit remained virtually the same as the off-line version; the difference being that a login screen with a Captcha, an automated challenge-response test, was added to protect against unwanted users. Links to the survey were added at the bottom of the page and end of the toolkit, to maximise the number of users that completed the survey, and an error submission form was added so that users could quickly report any problems.

Participants followed a link to a website with an introduction to the toolkit detailing how it would work as part of a service, hosted using Google Sites (see figure 13). From here it was requested that they use the toolkit from start to finish, saving their profile at the end; this provided valuable information on their running shoe use and aesthetic and comfort/performance preferences. During the session the participants' toolkit use was monitored using web analytics (web logfiles, page tagging). Once finished with the toolkit they completed a survey hosted on the introduction site. 


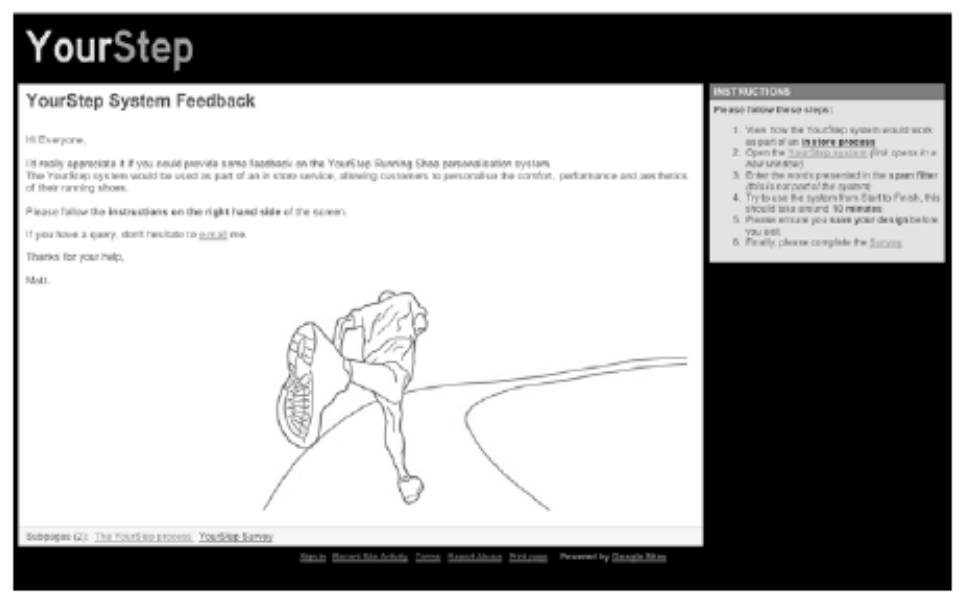

Figure 13: The YourStep Introduction \& Survey Site

Thirty-seven statements with Likert scales were used in the survey, covering the different objectives of the testing: usability, visual aspects and communication, functionality and the overall experience. Positive and negative statements were employed to minimise fatigue and pattern answering (Brace, 2008). Space for qualitative feedback was provided at the end of each section, allowing users to submit any important additional feedback. The survey was designed with reference to a series of industry standard interaction surveys (Tullis \& Albert, 2008); examples include the System Usability Scale (SUS), the Computer System Usability Questionnaire (CSUQ) and the Questionnaire for User Interface Satisfaction (QUIS). As it was intended that the session should take no longer than 30 minutes, to encourage participation, session duration was also monitored.

\section{Participants}

As of the $24^{\text {th }}$ of January 2011,131 people had completed the survey, around $22 \%$ of all that followed the link. Of the 131 participants that completed the survey in total, 76 were males and 55 females (see table 6). Nearly three-quarters of the participants were between 18 and 35 . These age ranges match with those outlined in the research as most likely to be interested in footwear personalisation (Head, et al., 2010). Participants were drawn predominantly from the United Kingdom (76.3\%) with just under 7\% from the United States. The remaining participants came from 15 other countries spread over five different continents. 58\% of participants were based in higher education, at university, with $30.5 \%$ undergraduate students. 
Table 6: Online Testing Participants

\begin{tabular}{|l|c|c|c|c|}
\hline AGE GROUP & Male & Female & Total & \% Age of Sample \\
\hline $18-25$ & 35 & 20 & 55 & 42.0 \\
\hline $26-35$ & 23 & 20 & 43 & 32.8 \\
\hline $36-45$ & 10 & 9 & 19 & 14.5 \\
\hline $46-55$ & 6 & 5 & 11 & 8.4 \\
\hline $56-65$ & 2 & 1 & 3 & 2.3 \\
\hline Overall & 76 & 55 & 131 & 100.0 \\
\hline
\end{tabular}

\section{Analysis of the Findings}

In this section the key findings with respect to the outlined objectives are detailed.

\section{Usability}

Table 7 shows the results for the key usability statements. The majority of participants found the toolkit easy to use, clear and well organised. Most also felt comfortable using the service and disagreed with the statement that the service was too inconsistent to use. The comfort rating may have been influenced by where and when they completed the survey, testing in an in store environment may deliver different results.

Table 7: Usability Statement Answers

\begin{tabular}{|l|c|c|c|c|c|}
\hline \multirow{2}{*}{ STATEMENT } & \multicolumn{5}{|c|}{ ANSWERS (\%) } \\
\cline { 2 - 6 } & Strongly \\
Disagree & Disagree & $\begin{array}{c}\text { Neither } \\
\text { Agree } \\
\text { nor } \\
\text { Disagree }\end{array}$ & Agree & $\begin{array}{c}\text { Strongly } \\
\text { Agree }\end{array}$ \\
\hline $\begin{array}{l}\text { I thought the service was easy to } \\
\text { use }\end{array}$ & 0.8 & 0.8 & 5.3 & 51.1 & 42.0 \\
\hline $\begin{array}{l}\text { I felt comfortable using this ser- } \\
\text { vice }\end{array}$ & 0.8 & 2.3 & 8.4 & 51.1 & 37.4 \\
\hline $\begin{array}{l}\text { I found the sequence of screens } \\
\text { clear and well organised }\end{array}$ & 0.0 & 2.3 & 6.1 & 51.1 & 40.5 \\
\hline $\begin{array}{l}\text { I thought the service was too incon- } \\
\text { sistent to use }\end{array}$ & 25.2 & 58.8 & 8.4 & 3.8 & 3.8 \\
\hline
\end{tabular}




\section{Visual Aspects and Communication}

Table 8 shows that the majority of participants felt the toolkit was attractive. Although a large number of participants liked the colours used in the presentation, nearly $25 \%$ were unsure or disliked the colours. This doesn't appear to be related to gender, a similar number of participants from each gender provided neutral or negative results. Most of those that chose the neutral statement were between 18 to 35 year old. Increasing the sample size and testing alternative colour schemes is necessary. The majority of participants, $83.2 \%$ felt that the service made their progress clear.

Table 8: Visual Aspects and Communication Statement Answers

\begin{tabular}{|l|l|l|l|l|l|}
\hline \multirow{2}{*}{ STATEMENT } & \multicolumn{5}{|c|}{ ANSWERS (\%) } \\
\cline { 2 - 7 } & $\begin{array}{c}\text { Strongly } \\
\text { Disagree }\end{array}$ & Disagree & $\begin{array}{c}\text { Neither } \\
\text { Agree nor } \\
\text { Disagree }\end{array}$ & Agree & $\begin{array}{l}\text { Strongly } \\
\text { Agree }\end{array}$ \\
\hline It is an attractive looking service & 0.8 & 3.8 & 7.6 & 55.7 & 32.1 \\
\hline $\begin{array}{l}\text { I liked the colours used in the } \\
\text { presentation }\end{array}$ & 0.0 & 5.3 & 17.6 & 55.0 & 22.1 \\
\hline $\begin{array}{l}\text { The service made my progress } \\
\text { clear }\end{array}$ & 0.8 & 2.3 & 13.7 & 51.1 & 32.1 \\
\hline
\end{tabular}

\section{Functionality}

The results for the functionality statements are presented in table 9. Nearly a third of participants felt they would have liked more help with decisions; despite the help being there some participants need to interact with someone, this was confirmed by some of the additional comments. This help was not necessarily desired from a technical person, e.g. a store assistant, nearly three-quarters of the participants were happy without them. Further development is required on integrating peer involvement more effectively. This additional help appears more desired than required; almost three quarters of the participants easily located the information necessary to facilitate their decision-making.

Over a third of the participants were either unsure or unhappy with the functions and capabilities that the service provided. The additional comments revealed that participants desired further comfort and performance options and improved aesthetic options.

Concentrating on the different sections, the majority of participants felt that they understood why they were answering the questions and found them easy to answer.

Many of the participants were unsure as to whether the 'Explore' section was useful or easy to use; it is possible that without the context of the whole service, participants may have not fully understood the 'Explore' section. Therefore, testing of the toolkit as a part of a complete service is desirable.

Colouring the shoes was considered to an easy process by the majority of participants, however nearly $20 \%$ were unsure or found it a difficult process; comments show that it could be a more intuitive process. $41.2 \%$ of participants could not colour the shoes as they would have liked to; a number seeking a more subtle range of colours. 
The colour guidance and gallery features may require additional development, large percentages of participants were unsure as to whether they were useful features $(42.7 \%$ and $33.6 \%$ respectively). This may be because the features were not used but also because of the wording of the questionnaire, it was not obvious what these features were. Over a third of the participants were unsure or did not think the midsole design feature was useful; one participant stated that it was too easy to produce a bad result. Further development is required to refine this feature.

\section{Table 9: Functionality Statement Answers}

\begin{tabular}{|c|c|c|c|c|c|c|}
\hline \multirow[t]{2}{*}{ STATEMENT } & \multicolumn{6}{|c|}{ ANSWERS (\%) } \\
\hline & $\begin{array}{l}\text { Strongly } \\
\text { Disagree }\end{array}$ & Disagree & $\begin{array}{c}\text { Neither Agree } \\
\text { nor } \\
\text { Disagree }\end{array}$ & Agree & $\begin{array}{c}\text { Strongly } \\
\text { Agree }\end{array}$ & Blank \\
\hline I would have liked more help with decisions & 3.1 & 43.5 & 20.6 & 25.2 & 5.3 & 2.3 \\
\hline $\begin{array}{l}\text { I think I would need the support of a technical } \\
\text { person to use this service }\end{array}$ & 34.4 & 39.7 & 11.5 & 10.7 & 3.1 & 0.8 \\
\hline $\begin{array}{l}\text { This service has all the functions and capabil- } \\
\text { ities I wish for }\end{array}$ & 3.1 & 13 & 19.8 & 52.7 & 9.9 & 1.5 \\
\hline $\begin{array}{l}\text { It was easy to find the information I needed } \\
\text { to make decisions }\end{array}$ & 0.8 & 2.3 & 19.8 & 58.8 & 14.5 & 3.8 \\
\hline $\begin{array}{l}\text { I am satisfied with the different type of shoe } \\
\text { upper choices }\end{array}$ & 4.6 & 8.4 & 21.4 & 51.9 & 11.5 & 2.3 \\
\hline $\begin{array}{l}\text { I am satisfied with the different type of shoe } \\
\text { outsole choices }\end{array}$ & 3.8 & 6.9 & 19.8 & 55 & 12.2 & 2.3 \\
\hline The questions were easy to answer & 0 & 1.5 & 6.9 & 67.2 & 22.9 & 1.5 \\
\hline $\begin{array}{l}\text { I understood why I was answering the ques- } \\
\text { tions }\end{array}$ & 0 & 8.4 & 6.1 & 63.4 & 21.4 & 0.8 \\
\hline The 'Explore' section was easy to use & 0 & 1.5 & 23.7 & 55.7 & 16.8 & 2.3 \\
\hline The 'Explore' section was useful & 0.8 & 1.5 & 29.8 & 52.7 & 13 & 2.3 \\
\hline Colouring the shoes was an easy process & 3.1 & 8.4 & 8.4 & 51.9 & 27.5 & 0.8 \\
\hline I was able to colour the shoes as I wanted & 5.3 & 20.6 & 15.3 & 40.5 & 17.6 & 0.8 \\
\hline The colour guidance feature was useful & 2.3 & 9.2 & 42.7 & 32.1 & 12.2 & 1.5 \\
\hline I found the gallery easy to use & 0 & 5.3 & 32.1 & 49.6 & 11.5 & 1.5 \\
\hline The gallery section was useful & 0 & 5.3 & 33.6 & 46.6 & 11.5 & 3.1 \\
\hline $\begin{array}{l}\text { It was easy to personalise the midsole with } \\
\text { my design }\end{array}$ & 0 & 7.6 & 22.1 & 46.6 & 22.9 & 0.8 \\
\hline I found the midsole design features useful & 2.3 & 9.2 & 27.5 & 43.5 & 14.5 & 3.1 \\
\hline
\end{tabular}




\section{Overall Experience}

The majority of participants were satisfied with the service and how long they spent on the toolkit. This may be due in part to the experience delivered; most thought it was an engaging and fun experience. A large number of these participants, around $75 \%$, were interested in using this service to purchase running shoes and recommending it to a friend. For both statements nearly $20 \%$ of participants were unsure; this may be because there are elements of the service missing and, most importantly, no product.

The results indicate that the toolkit was easy to use and delivered an enjoyable experience. The aesthetic options require further development; the colour selections need refining and the midsole section needs explaining more clearly to participants. The random colours, colour guidance and gallery features could all be advertised more clearly; some of the issues participants experienced with colour selection may have been avoided if they used these features.

Testing the toolkit as part of an in store service, with an assistant taking measurements and fitting shoes is a desirable next step. This will provide a better indication of how comfortable the participants feel using the toolkit and the additional help they require. Evaluating the 'Explore' section in this context will also provide a more accurate reflection of its suitability as part of a running shoe personalisation process.

Table 10: Overall Experience Answers

\begin{tabular}{|l|c|c|c|c|c|}
\hline \multirow{2}{*}{ STATEMENT } & \multicolumn{5}{|c|}{ ANSWERS (\%) } \\
\cline { 2 - 6 } & $\begin{array}{l}\text { Strongly } \\
\text { Disagree }\end{array}$ & Disagree & $\begin{array}{c}\text { Neither } \\
\text { Agree nor } \\
\text { Disagree }\end{array}$ & Agree & $\begin{array}{c}\text { Strongly } \\
\text { Agree }\end{array}$ \\
\hline $\begin{array}{l}\text { I would be interested in using this } \\
\text { service to purchase running shoes }\end{array}$ & 3.1 & 9.2 & 19.1 & 45 & 23.7 \\
\hline $\begin{array}{l}\text { I would recommend this service to a } \\
\text { friend }\end{array}$ & 0.8 & 4.6 & 18.3 & 50.4 & 26 \\
\hline $\begin{array}{l}\text { Overall, I am satisfied with this ser- } \\
\text { vice }\end{array}$ & 0.8 & 2.3 & 11.5 & 64.1 & 21.4 \\
\hline This service is fun to use & 0.8 & 1.5 & 15.3 & 52.7 & 29.8 \\
\hline $\begin{array}{l}\text { I found using this service an enga- } \\
\text { ging experience }\end{array}$ & 0.8 & 3.1 & 8.4 & 69.5 & 18.3 \\
\hline $\begin{array}{l}\text { I am satisfied with the time it took } \\
\text { to use this service }\end{array}$ & 0 & 0.8 & 9.9 & 61.1 & 28.2 \\
\hline
\end{tabular}

\section{Limitations}

There were limitations to the results found during this testing. The homogeneity of the participants means findings should not be taken as being representative of the whole market. Instead they provide a useful insight of a select group of users' opinions of the YourStep toolkit. No help guide was provided to using the toolkit; some participants may have struggled to locate certain aspects of the toolkit, resulting in increased percentages of neutral selections. 


\section{Conclusion}

When designing the YourStep toolkit the aim was to develop a collaborative design tool that satisfied the needs of those who wanted to personalise their running shoes, addressing the perceived gap in the market. The toolkit was designed with a focus on the comfort and fit of the footwear, the most important aspects to consumers (Head, et al., 2009; Marti, 1989; Collazzo, 1988), and as part of an in store process, allowing the consumer to try on the shoes and establish a physical and emotional bond.

The level of interest for using such a service was high amongst participants and test results were positive with regards to the usability, visual aspects and the design of the experience; the participants finding the toolkit well organised, attractive, consistent, and easy to use, lending to an enjoyable, engaging experience. The results were more mixed for the functionality, participants were unsure about some of the features and desired more comfort and performance and aesthetic choices; a more effective assessment of the functionality is desired. The automatic capture of the users' profile data during testing provides information to improve the toolkit and demonstrates the ease with which a provider can obtain feedback on their consumers' requirements, ensuring they are delivering what is desired.

Testing within an in store context will provide a more accurate reflection of the suitability of the toolkit; some consumers found it hard to provide an opinion on functions taken out of context. Concurrently, research has been, and is being, undertaken within the Elite to High Street project (Salles \& Gyi, 2010; Gyi, Salles \& Porter, 2008; Toon, et al., 2009) concerning the most appropriate way to implement such a service.

\section{References}

Babb, L., 2008. RE: NB Wear Test questionnaires [E-mail]. Message to: M. Head. 21 July 2008.

Bardill, A., Herd, K. and Karamanoglu, M., 2007. Product envelopes: designing positive interplay between brand DNA and customer co-designers. International Journal of Mass Customisation, 2(1-2), pp. 57-2.

Bellizzi, J.A., Crowley, A.E. and Hasty, R.W., 1983. The effects of color on store design. Journal of Retailing, 68(4), pp. 21-45.

Benyon, D., Turner, P. and Turner, S., 2005. Designing Interactive Systems: People, Activities, Contexts, Technologies. $1^{\text {st }}$ edn. Harlow: Addison-Wesley.

Brace, I., 2008. Questionnaire Design: How to plan, structure and write survey material for effective market research. $2^{\text {nd }}$ edn. London: Kogan Page.

Collazzo, C., 1988. A 1986-1987 Study of Consumer Problems in Shopping for Footwear with Emphasis on Size and Fit. Journal of Testing and Evaluation, 16(4), pp. 421-424.

Franke, N. and Piller, F., 2004. Value Creation by Toolkits for User Innovation and Design: The Case of the Watch Market. Journal of Product Innovation Management, 21(6), pp. 401-415.

Franke, N., Schreier, M. and Kaiser, U., 2010. The "I Designed It Myself” Effect in Mass Customization. Management Science, 56(1), pp. 125-140.

Goonetilleke, R., 2003. 'Designing footwear: back to basics in an effort to design for people', In: H.M. Khalid, T.Y. Lim and N.K. Lee., eds, Proceedings of SEAMEC 2003, May 2003, Kuching, pp. 25-31.

Gyi, D.E., Salles, A. and Porter, J.M., 2009. Elite to high street footwear: the role of anthropometric data. In: T. Lotus, M. Reitenbach and J. Molenbroek., eds, Proceeding of the 9th International Congress of Physiological Anthropology. $1^{\text {st }}$ edn. Faculty of Industrial Design Engineering: The Netherlands, pp. 53-56. 
Hague, R., Campbell, I. and Dickens, P., 2003. 'Implications on design of rapid manufacturing'. Proceedings of the Institution of Mechanical Engineers, Part C (Journal of Mechanical Engineering Science), 217, pp. 25-30.

Head, M.J., Porter, C.S and Summerskill, S., 2009. Specifying a system to facilitate the design by consumers of personalised sports footwear. 5th World Congress on Mass Customization and Personalization, October 2009, Helsinki.

Head, M.J., Porter, C.S. and Toon, D., 2010. Delivering Pleasure: The Personalisation of Running Shoes. 7th International Conference on Design and Emotion, October 2010, Chicago.

Herd, K., Bardill, A. and Karamanoglu, M., 2007. Designing for co-design: using the product envelope model as a framework for reflection. London: University of Middlesex.

International Organization for Standardization. 2002. Ergonomics of human-system interaction: usability methods supporting human-centred design. Geneva: ISO.

Krauss, I., Valiant, G., Horstmann, T. and Grau, S., 2010. Comparison of Female Foot Morphology and Last Design in Athletic Footwear-Are Men's Lasts Appropriate for Women? Research in Sports Medicine: An International Journal, 18(2), pp. 140.

Krug, S., 2006. Don't Make Me Think: A Common Sense Approach to Web Usability. $2^{\text {nd }}$ edn. Berkeley: New Riders.

Langford, J.D. and McGonagh, D., 2003. Focus groups supporting effective product development. London: Taylor \& Francis.

Lazar, J., 2006. Web Usability: A User-Centered Design Approach. $1^{\text {st }}$ edn. Boston: Addison-Wesley.

Marti, B., 1989. 'Relationships between running injuries and running shoes'. In: B. Segesser and W. Pforringer, eds, The shoe in sport. London: Year Book Medical Publishers, pp. 256-265.

Middlestadt, S.E., 1990. The Effect of Background and Ambient Color on Product Attitudes and Beliefs. Advances in Consumer Research, 17(1), pp. 244-249.

Mintel Marketing Intelligence, 2010. Sports Goods Retailing. London: Mintel International Group.

Mintel Marketing Intelligence. 2008. Sports Goods Retailing. London: Mintel International Group.

Mintel Marketing Intelligence. 2007. Sports Participation. London: Mintel International Group.

Moggridge, B., 2007. Designing Interactions. 1st edn. London: MIT Press.

Nielsen, J. and Tahir, M., 2002. Homepage usability: 50 websites deconstructed. $1^{\text {st }}$ edn. Indianapolis: New Riders.

NPD Group Inc., 2008. Peer Summary-Athletic Footwear POS Data-Period: May 2008. Port Washington: NPD Group Inc.

Pine, B. J. and Gilmore, J.H., 1998. Welcome to the Experience Economy. Harvard business review, 76(4), pp. 97-105.

Polyani, M., 1958. Personal knowledge: towards a post-critical philosophy. $1^{\text {st }}$ edn. Florence: Routledge.

Raskin, J., 2000. The Humane Interface: new directions for designing interactive systems. $1^{\text {st }} \mathrm{edn}$. Reading, MA: Addison Wesley.

Redaelli, C., Sacco, M., Dulio, S., and Boer, C. R., 2005. Analysis of cultural gap for customised product. $3^{\text {rd }}$ Interdisciplinary World Congress on Mass Customisation and Personalization. Hong Kong.

Rogoll, T. and Piller, F., 2004. Product Configuration from the customer's perspective: a comparison of configuration systems in the apparel industry, International Conference on Economic, Technical and Organisational Aspects of Product Configuration Systems, June 2004.

Salles, A.S. and Gyi, D.E., 2010. The specification and evaluation of personalised footwear for additive manufacturing. In: W. Karwowski and G. Salvendy, eds, Advances in Human Factors, Ergonomics, and Safety in Manufacturing and Service Industries. $1^{\text {st }}$ edn. Taylor \& Francis: CRC Press, pp. 355-366.

Scheuing, E.E. and Johnson, E.M., 1989. A Proposed Model for New Service Development. Journal of Services Marketing, 3(2).

Shostack, G.L., 1982. How to Design a Service. European Journal of Marketing, 16(1), pp. 49-63. 
Stuhlfaut, A. and Sullivan, D., 2007. The Athletic Insight: The Sole Source for Athletic Consumer Data. Babson College: The Athletic Insight.

Toon, D., Majewski, C., Zarringhalam, H., Hopkinson, N. and Caine, M., 2008. 'A Novel Approach to Personalising the Mechanical Properties of Sprint Footwear (P179)'. The Engineering of Sport. 7(2) pp. 20-213.

Tullis, T. and Albert, B., 2008. Measuring the User Experience: Collecting, Analyzing, and Presenting Usability Metrics. $1^{\text {st }}$ edn. Burlington: Morgan Kaufmann.

Williams, R., 2010. Client reinvention: building the most flexible and effective value chain [Online]. Available at: http://en.community.dell.com/dell-blogs/dell-shares/b/dell-shares/archive/2010/

03/11/client-reinvention-building-the-most-flexible-and-effective-value-chain.aspx [Accessed April $\left.18^{\text {th }}, 2011\right]$.

Witana, C., 2004. 'Dimensional differences for evaluating the quality of footwear fit'. Ergonomics, 47(12), pp. 1301-1317.

Yessin, J., 2008. Creating Holistic Customized Solutions: the role of Design in the Mass Customization Process. A Thesis submitted in partial fulfillment of the Requirements of Savannah College of Art and Design for Master of Fine Arts. Savannah, GA: Savannah College of Art and Design.

\section{About the Authors}

Matthew Head

Matthew Head is a PhD researcher in the Design Ergonomics Research Group at Loughborough University. He studied Product Design and Innovation at the University of Portsmouth, graduating with First Class Honours, and joined the Elite to High Street project in 2008. This project investigates the design of personalised sports footwear and Matthew's research focuses on the exploration of the personalisation process for running shoes within the retail environment.

Dr. C. Samantha Porter

Dr. Samantha Porter is a senior lecturer at Loughborough University. Her background is in ergonomics, applied psychology and design ergonomics. Her research reflects the breadth of her interests; these include product pleasure, tools and methods for designing for emotion, the design of the person/product interface of medical/medical related products and personalisation and product attachment. 



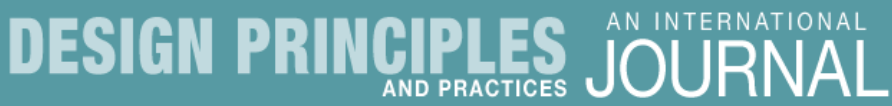

\section{Editor}

Bill Cope, University of Illinois, Urbana-Champaign, USA.

\section{Editorial Advisory Board}

Genevieve Bell - Intel Corporation, Santa Clara, USA.

Michael Biggs - University of Hertfordshire, Hertfordshire, UK.

Jeanette Blomberg - IBM Almaden Research Center, San Jose, USA.

Peter Burrows - RMIT University, Melbourne, Australia.

Bill Cope - University of Illinois, Urbana-Champaign, USA

Patrick Dillon - Exeter University, Exeter, UK.

Michael Gibson - University of North Texas, Denton, USA.

Loredana Di Lucchio, Sapienza Universita di Roma, Rome, Italy.

Judith Gregory - IIT Institute of Design, Chicago, USA; University of Oslo, Oslo, Norway.

Tracy S. Harris - The American Institute of Architects, Washington, D.C., USA

Clive Holtham - City of London University, London, UK.

Lorenzo Imbesi, Carleton University, Ottawa, Canada.

Hiroshi Ishii - MIT Media Lab, Cambridge, USA.

Gianni Jacucci - University of Trento, Trento, Italy.

Mary Kalantzis - University of Illinois, Urbana-Champaign, USA.

Klaus Krippendorff - University of Pennsylvania, Philadelphia, USA.

Terence Love - Curtin University, Perth, Australia.

Bill Lucas - MAYA Fellow, MAYA Design, Inc., Pittsburgh, USA.

Ezio Manzini - Politecnico of Milano, Milan, Italy.

Mario Minichiello, Birmingham Institute of Art and Design, Birmingham, UK.

Mahendra Patel - Leaf Design, Mumbai, India.

Toni Robertson - University of Technology Sydney, Sydney, Australia.

Terry Rosenberg - Goldsmiths, University of London, London, UK.

Keith Russell - University of Newcastle, Callaghan, Australia.

Maria Cecilia Loschiavo dos Santos - University of São Paulo, São Paulo, Brazil.

Please visit the Journal website at http://www.Design-Journal.com for further information about the Journal or to subscribe. 


\section{The Design Principles \& Practices Community}

This knowledge community is brought together by a shared interest in the process of design and their conceptual foundations. The community interacts through an innovative, annual face-to-face conference, as well as year-round virtual relationships in a weblog, peer reviewed journal and book imprint - exploring the affordances of the new digital media. Members of this knowledge community include academics, designers, administrators, educators, consultants and research students.

\section{Conference}

Members of the Design Community meet at the International Conference on Design Principles and Practices, held annually in different locations around the world. The Design Conference was held at Imperial College London, in 2007; in conjunction with the University of Miami, Florida, USA in 2008; at Technical University Berlin, Germany in 2009; at the University of Illinois at Chicago, USA in 2010; and at Sapienza University of Rome, Italy in 2011. In 2012, the conference will be held at the University of California, Los Angeles, USA.

Our community members and first time attendees come from all corners of the globe. Intellectually, our interests span the breadth of the field of design. The Conference is a site of critical reflection, both by leaders in the field and emerging scholars and practitioners. Those unable to attend the Conference may opt for virtual participation in which community members can either submit a video and/or slide presentation with voice-over, or simply submit a paper for peer review and possible publication in the Journal.

Online presentations can be viewed on YouTube.

\section{Publishing}

The Design Community enables members of its community to publish through three media. First, by participating in the Design Conference, community members can enter a world of journal publication unlike the traditional academic publishing forums - a result of the responsive, non-hierarchical and constructive nature of the peer review process. Design Principles and Practices: An International Journal provides a framework for double-blind peer review, enabling authors to publish into an academic journal of the highest standard.

The second publication medium is through the book series On Design, publishing cutting edge books in print and electronic formats. Publication proposals and manuscript submissions are welcome.

The third major publishing medium is our news blog, constantly publishing short news updates from the Design Community, as well as major developments in the field of design. You can also join this conversation at Facebook and Twitter or subscribe to our email Newsletter. 


\section{Common Ground Publishing Journals}

\begin{tabular}{|c|c|}
\hline $\begin{array}{l}\text { AGING } \\
\text { Aging and Society: An Interdisciplinary Journal } \\
\text { Website: http://AgingAndSociety.com/journal/ }\end{array}$ & $\begin{array}{c}\text { ARTS } \\
\text { The International Journal of the Arts in Society. } \\
\text { Website: www.Arts-Journal.com }\end{array}$ \\
\hline $\begin{array}{l}\text { BOOK } \\
\text { The International Journal of the Book } \\
\text { Website: www.Book-Journal.com }\end{array}$ & $\begin{array}{c}\text { CLIMATE CHANGE } \\
\text { The International Journal of Climate Change: } \\
\text { Impacts and Responses } \\
\text { Website: www.Climate-Journal.com }\end{array}$ \\
\hline $\begin{array}{c}\text { CONSTRUCTED ENVIRONMENT } \\
\text { The International Journal of the } \\
\text { Constructed Environment } \\
\text { Website: www.ConstructedEnvironment.com/journal }\end{array}$ & $\begin{array}{c}\text { DESIGN } \\
\text { Design Principles and Practices: } \\
\text { An International Journal } \\
\text { Website: www.Design-Journal.com }\end{array}$ \\
\hline $\begin{array}{c}\text { DIVERSITY } \\
\text { The International Journal of Diversity in } \\
\text { Organizations, Communities and Nations } \\
\text { Website: www.Diversity-Journal.com }\end{array}$ & $\begin{array}{l}\text { FOOD } \\
\text { Food Studies: An Interdisciplinary Journal } \\
\text { Website: http://Food-Studies.com/journal/ }\end{array}$ \\
\hline $\begin{array}{c}\text { GLOBAL STUDIES } \\
\text { The Global Studies Journal } \\
\text { Website: www.GlobalStudiesJournal.com }\end{array}$ & $\begin{array}{c}\text { HEALTH } \\
\text { The International Journal of Health, } \\
\text { Wellness and Society } \\
\text { Website: www.HealthandSociety.com/journal }\end{array}$ \\
\hline $\begin{array}{c}\text { HUMANITIES } \\
\text { The International Journal of the Humanities } \\
\text { Website: www. Humanities-Journal.com }\end{array}$ & $\begin{array}{c}\text { IMAGE } \\
\text { The International Journal of the Image } \\
\text { Website: www.Onthelmage.com/journal }\end{array}$ \\
\hline $\begin{array}{l}\text { LEARNING } \\
\text { The International Journal of Learning. } \\
\text { Website: www.Learning-Journal.com }\end{array}$ & $\begin{array}{c}\text { MANAGEMENT } \\
\text { The International Journal of Knowledge, } \\
\text { Culture and Change Management. } \\
\text { Website: www.Management-Journal.com }\end{array}$ \\
\hline $\begin{array}{c}\text { MUSEUM } \\
\text { The International Journal of the Inclusive Museum } \\
\text { Website: www.Museum-Journal.com }\end{array}$ & $\begin{array}{c}\text { RELIGION AND SPIRITUALITY } \\
\text { The International Journal of Religion and } \\
\text { Spirituality in Society } \\
\text { Website: www.Religion-Journal.com }\end{array}$ \\
\hline $\begin{array}{c}\text { SCIENCE IN SOCIETY } \\
\text { The International Journal of Science in Society } \\
\text { Website: www.ScienceinSocietyJournal.com }\end{array}$ & $\begin{array}{c}\text { SOCIAL SCIENCES } \\
\text { The International Journal of Interdisciplinary } \\
\text { Social Sciences } \\
\text { Website: www.SocialSciences-Journal.com }\end{array}$ \\
\hline $\begin{array}{c}\text { SPACES AND FLOWS } \\
\text { Spaces and Flows: An International Journal of } \\
\text { Urban and ExtraUrban Studies } \\
\text { Website: www.SpacesJournal.com }\end{array}$ & $\begin{array}{c}\text { SPORT AND SOCIETY } \\
\text { The International Journal of Sport and Society } \\
\text { Website: www.sportandsociety.com/journal }\end{array}$ \\
\hline $\begin{array}{c}\text { SUSTAINABILITY } \\
\text { The International Journal of Environmental, Cultural, } \\
\text { Economic and Social Sustainability } \\
\text { Website: www.Sustainability-Journal.com }\end{array}$ & $\begin{array}{c}\text { TECHNOLOGY } \\
\text { The International Journal of Technology, } \\
\text { Knowledge and Society } \\
\text { Website: www.Technology-Journal.com }\end{array}$ \\
\hline $\begin{array}{c}\text { UBIQUITOUS LEARNING } \\
\text { Ubiquitous Learning: An International Journal } \\
\text { Website: www.ubi-learn.com/journal/ }\end{array}$ & $\begin{array}{l}\text { UNIVERSITIES } \\
\text { Journal of the World Universities Forum } \\
\text { Website: www.Universities-Journal.com }\end{array}$ \\
\hline
\end{tabular}

For subscription information please contact subscriptions@commongroundpublishing.com 